\title{
Peningkatan Pengetahuan Ibu Tentang Gizi Seimbang Untuk Mencegah Permasalahan Gizi Pada Balita di Kabupaten Jember
}

\author{
Ria Chandra Kartika ${ }^{1 *}$, Erna Selviyanti ${ }^{2}$, Dessya Putri Ayu Umbaran ${ }^{3}$, Dina Fitriyah ${ }^{4}$, Yohan Yuanta ${ }^{5}$ \\ 1,2,3,4,5 Jurusan Kesehatan, Politeknik Negeri Jember \\ ${ }^{1}$ ria_chandra@polije.ac.id, =2ernaselviyanti@polije.ac.id, ${ }^{3}$ dessya.putri@polije.ac.id, ${ }^{4}$ dinafitriyah@polije.ac.id, \\ 5 yohan_yuanta@polije.ac.id
}

\begin{abstract}
One of the characteristics of a developed nation is a nation that has a high level of health, intelligence and work productivity. These three things are strongly influenced by the state of nutrition. Nutritional problems in Indonesia are currently included in the triple burden of nutrition status. The prevalence of stunting under five in Indonesia is included in the chronic category, which is $30.8 \%$. The direct cause of nutritional problems in toddlers is due to an unbalanced diet. Balanced nutrition is a food composition from a variety of food ingredients that contain nutrients needed by the body, both in quality and quantity. One of the efforts to prevent nutritional problems in toddlers is to empower parents of toddlers through increasing the knowledge of mothers of toddlers. The role of the mother is very important for toddlers to fulfill balanced nutrition because the level of knowledge about nutrition will affect the food selection process and family eating behavior. Therefore, this community service program is to carry out balanced nutrition counseling activities that aim to increase the knowledge of mothers of toddlers about balanced nutrition to prevent nutritional problems in toddlers. The target of this activity is mothers of children under five at Posyandu Catleya 19. The implementation of this activity was attended by mothers of children under five at Posyandu Catleya 19, posyandu cadres, and coordinating midwives. Counseling on balanced nutrition begins with pretest activities, then continues with material presentation, discussion and question and answer, and then closes with posttest. In this activity, mothers of children under five are given a balanced nutrition module which contains material on balanced nutrition and recipes that can be applied in daily feeding of children under five. The results of the activity evaluation showed that $76.3 \%$ of mothers under five experienced an increase in knowledge after counseling.
\end{abstract}

Keywords : Nutrition, Counseling, Stunting, Wasting, Obesity

\begin{abstract}
Abstrak
Salah satu ciri bangsa maju adalah bangsa yang memiliki tingkat kesehatan, kecerdasan dan produktivitas kerja yang tinggi. Ketiga hal ini sangat dipengaruhi oleh keadaan gizi. Permasalahan gizi di Indonesia saat ini masuk dalam status tripel burden of nutrition. Prevalensi balita stunting di Indonesia termasuk dalam kategori kronis, yaitu sebesar 30,8\%. Penyebab langsung permasalahan gizi pada balita adalah karena pola makan yang tidak seimbang. Gizi seimbang adalah susunan makanan dari beragam bahan makanan yang mengandung zat gizi yang dibutuhkan oleh tubuh, baik secara kualitas maupun kuantitasnya. Salah satu upaya pencegahan masalah gizi pada balita adalah dengan melakukan pemberdayaan kepada orang tua balita melalui peningkatan pengetahuan ibu balita. Peran ibu balita sangat pentingdalam pemenuhan gizi seimbang karena tingkat pengetahuan tentang gizi akan berpengaruh pada proses pemilihan makanan dan perilaku makan keluarga. Oleh karena itu, program pengabdian masyarakat ini adalah melakukan kegiatan penyuluhan gizi seimbang yang bertujuan untuk meningkatkan pengetahuan ibu balita tentang gizi seimbang untuk mencegah permasalahan gizi pada balita. Sasaran pada kegiatan ini adalah ibu balita di Posyandu Catleya 19. Pelaksanaan kegiatan ini dihadiri oleh ibu balita posyandu catleya 19, kader posyandu, dan bidan koordinator. Penyuluhan gizi seimbang dimulai dengan kegiatan pretest, kemudian dilanjutkan dengan pemaparan materi, diskusi dan tanya jawab, dan kemudian ditutup dengan postest. Pada kegiatan ini, ibu balita diberi modul gizi seimbang yang memuat tentang materi gizi seimbang dan resep masakan yang dapat diaplikasikan dalam pemberian makan anak balita sehari-hari. Hasil evaluasi kegiatan menunjukkan bahwa sebesar $76,3 \%$ ibu balita mengalami peningkatan pengetahuan setelah dilakukan penyuluhan
\end{abstract}

Kata Kunci: Gizi Seimbang Balita, Penyuluhan, Stunting, Wasting, Obesitas

*Penulis Korespondensi : Ria Chandra Kartika 


\section{PENDAHULUAN}

Salah satu ciri bangsa maju adalah bangsa yang memiliki tingkat kesehatan, kecerdasan dan produktivitas kerja yang tinggi. Permasalahan gizi di Indonesia saat ini masuk dalam status tripel burden of nutrition, artinya permasalahan gizi kurang belum dapat diatasi, namun sudah muncul masalah gizi lebih dan anemia. Di Indonesia, prevalensi balita stunting termasuk dalam kategori kronis, yaitu sebesar $30,8 \%$. Selain itu, juga terdapat $10,2 \%$ balita yang menderita wasting (Kementerian Kesehatan RI, 2019). Permasalahan gizi tersebut salah satunya disebabkan oleh ketidaksimbangan antara pola makan balita dengan kebutuhan gizi harian balita. Jika permasalahan gizi balita tersebut tidak diatasi, maka akan dapat mempengaruhi perkembangan hidup dan kesehatan balita tersebut hingga dewasa. (Almatsier, 2011).

Gizi seimbang adalah susunan makanan dari beragam bahan makanan yang mengandung zat gizi yang dibutuhkan oleh tubuh, baik secara kualitas maupun kuantitasnya. Permasalahan gizi lebih dan gizi kurang yang terjadi di Indonesia salah satu penyebabnya adalah kurangnya pengetahuan masyarakat tentang gizi seimbang. Kurangnya pengetahuan tentang gizi, akan mempengaruhi pola konsumsi individu tersebut. Apabila konsumsi harian tidak sesuai dengan kebutuhan harian individu, maka akan mengakibatkan terjadinya masalah gizi kurang maupun gizi lebih (Almatsier, 2011).

Berdasarkan data Riskesdas Tahun 2018 Status Balita dengan status gizi kurang dan tatus gizi buruk masih lebih dari $20 \%$ jumlah balita di kabupaten Jember. Ibu-ibu Balita memiliki peranan yang sangat penting bagi penentuan status gizi balita. Berdasarkam hasil analisis situasi, faktor penyebab primer terjadinya masalah gizi karena kurangnya kuantitas dan kualitas susunan makanan seseorang. Selain itu, permasalahan gizi pada balita sering kali disebabkan oleh kurangnya pemahaman orang tua terhadap pemenuhan gizi seimbang pada balita. Kurangnya pemahaman orang tua tentang masalah gizi, akan mempengaruhi sikap dan perilaku orang tua tersebut dalam praktik pemilihan dan penyediaan menu makanan anaknya. Sehingga, apabila menu makanan yang diberikan kepada anak tidak sesuai dengan kebutuhan anak, maka akan dapat menimbulkan permasalahan gizi (Fadila, 2017).

Sikap dan perilaku ibu dalam praktik pemberian makan anak akan berpengaruh terhadap selera makan anak selanjutnya. Sehingga sebagai salah satu upaya pemenuhan gizi, anak sebaiknya dikenalkan dengan beragam makanan. Pengenalan makanan beragam pada anak sangat penting dilakukan, seperti contohnya anak balita usia 6 bulan mulai diberikan sayuran, buah-buahan, lauk pauk sumber protein nabati dan hewani, serta makanan pokok sebagai sumber kalori (Almatsier, 2011).

Beberapa hasil penelitian menunjukkan bahwa terdapat hubungan antara pengetahuan ibu dengan status gizi anak. Hal tersebut terjadi karena ibu adalah penentu makanan yang dikonsumsi oleh anak. Kurangnya pengetahuan tentang gizi dan kesehatan menjadi salah satu penyebab terjadinya kekurangan gizi pada anak. Seorang ibu, harus memiliki pengetahuan dan keterampilan dasar tentang menu sehat dan bergizi seimbang (Fadila, 2017).

Pemahaman Gizi seimbang pada balita adalah salah satu kunci keberhasilan dalam pencegahan dan penyelesaian masalah gizi. Sehingga penting bagi orang tua di yang tinggal di wilayah kerja Posyandu Catleya 19 untuk memahami tentang gizi seimbang pada balita. Oleh karena itu, perlu adanya peningkatan pengetahuan dan pemahaman pada ibu balita tentang gizi seimbang melalui penyuluhan tentang gizi seimbang di Posyandu Catleya 19 Kecamatan Sumbersari, Kabupaten Jember. Sehingga, dengan meningkatnya pengetahuan ibu balita dapat mencegah terjadinya permasalahan gizi pada balita.

\section{METODE}

Kegiatan pengabdian masyarakat merupakan salah satu kegiatan yang memiliki focus pada upaya kemandirian masyarakat. Dengan dilakukan kegiatan penyuluhan gizi seimbang ini, diharapkan ibu balita dapat secara berdaya dan mandiri melakukan praktek pemberian makan yang sesuai dengan pedoman gizi seimbang. Sehingga dapat mengatasi permasalahan gizi yang terjadi pada anak balita.

Pengabdian masyarakat ini dilakukan pada bulan Desember 2019 di Posyandu Catleya 19, Kecamatan Sumbersari Kabupaten Jember. Sebelum melakukan 
kegiatan pengabdian, tim melakukan kegiatan identifikasi permasalahan mitra untuk menganalis permasalahan gizi di Posyandu Catleya 19 dan kemudian merumuskan kegiatan intervensi yang sesuai dengan permasalahan mitra. Selanjutnya tim berkoordinasi dengan mitra terutama dengan kader posyandu catleya 19 dan bidan koordinator Puskesmas Sumbersari tentang teknis pelaksanaan kegiatan. Selain itu, tim juga mempersiapkan media penyuluhan kegiatan berupa modul penyuluhan gizi seimbang pada balita.

Pelaksanaan kegiatan pengabdian masyarakat penyuluhan gizi seimbang dilakukan pada bulan Desember tahun 2019. Peserta pada kegiatan ini adalah ibu balita di Posyandu Catleya 19 Kecamatan Sumbersari Kabupaten Jember.

Sebelum melakukan penyuluhan, tim melakukan pre-test untuk mengetahui tingkat pengetahuan ibu balita tentang gizi seimbang pada balita. Kemudian, dilanjutkan dengan pemaparan materi penyuluhan gizi seimbang, dan dilanjutkan dengan diskusi, dan tanya jawab. Kegiatan penyuluhan diakhiri dengan posttest untuk mengevaluasi peningkatan penngetahuan peserta setelah penyuluhan. Ibu balita yang hadir dalam kegiatan ini mendapatkan modul materi tentang gizi seimbang pada balita, sehingga diharapkan ibu balita dapat menggunakan buku tersebut sebagai pedoman dalam penyusunan menu makanan untuk balita.

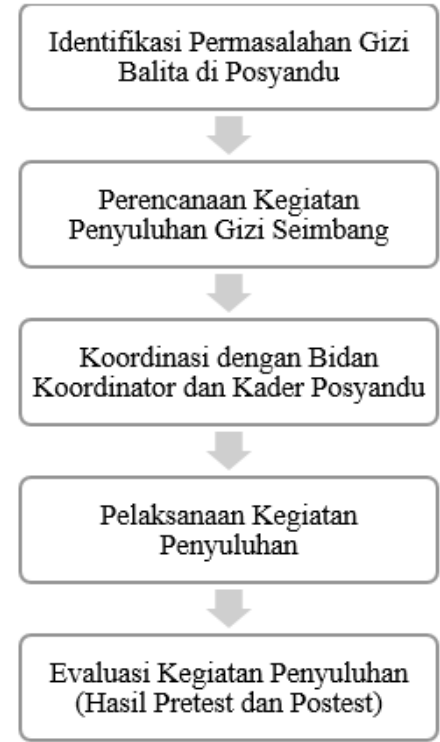

Gambar 1. Alur Kegiatan Penyuluhan Gizi Seimbang

\section{HASIL DAN PEMBAHASAN}

Indonesia dalam kacamata gizi sedang mengalami situasi triple burden of nutrition atau tugas beban mal nutrisi. Kondisi ini mengacu pada kekurangan, kelebihan dan ketidakseimbangan dari asupan gizi yang dikonsumsi oleh seseorang. Kurangnya asupan gizi yang dikonsumsi akan menyebabkan stunting, wasting, dan underweight. Sedangkan kelebihan asupan gizi juga menyebabkan masalah gizi seperti obesitas. Jika obesitas tidak dapat dikendalikan makan akan memicu timbulnya penyakit kardiovaskular seperti hipertensi, jantung dan pembulu darah, stroke dan penyakit lainnya (Kementerian PPN Bappenas, 2019). Kelebihan masalah gizi tersebut terjadi karena kelebihan asupan makanan dan minuman tinggi energi lemak, gula dan garam, dan asupan yang rendah serat, serta kurangnya aktivitas fisik (Kementerian Kesehatan RI, 2014)

Tumbuh kembang anak merupakan investasi masa depan suatu bangsa.Kualitas yang terbangun dengan baik, akan memberikan kontribusi yang signifikan terhadap kemajuan sebuah negara.Seribu hari pertama kehidupan merupakan periode emas atau yang dikenal dengan Golden Ageatau disebut juga sebagai waktu yang kritis, yang jika tidak dimanfaatkan dengan baik dapat menyebabkan kerusakanyang bersifat permanen (Etikasari, 2020). Di indonesia, banyak sekali permasalahan gizi baik itu stunting, obesitas, dan wasting pada balita, obesitas pada orang dewasa, dan anemia pada ibu hamil (Kementerian Kesehatan RI, 2019). Banyak sekali faktor yang menyebabkan terjadinya masalah gizi baik itu factkr langsung maupun faktor tidak langsung. Salah Satu upaya pencegahan masalah gizi pada balita adalah dengan melakukan pemberdayaan kepada orang tua balita salah satunya adalah peningkatan pengetahuan ibu balita (Almatsier, 2011).

Peran ibu balita penting dalam pemenuhan gizi seimbang karena tingkat pengetahuan tentang gizi akan berpengaruh pada proses pemilihan makanan dan perilaku makan keluarga (Rahardjo, 2017). Konsep tersebutlah yang diadobsi dalam pemberdayaan masyarakat ini yaitu dengan cara meningkatkan pengetahuan ibu tentang gizi seimbang untuk mencegah 
permasalahan gizi anak di Kabupaten Jember, khususnya di Posyandu Catleya 19.

Gizi seimbang adalah susunan makanan sehari-hari yang mengandung zat gizi dalam jenis dan jumlah yang sesuai dengan kebutuhan tubuh, dengan memperhatikan prinsip keanekaragaman pangan, aktivitas fisik, perilaku hidup bersih dan mempertahankan berat badan normal untuk mencegah masalah gizi. Status gizi individu erat kaitannya dengan pola makan yang dikonsumsi oleh individu. Sehingga untuk mencegah terjadinya masalah gizi, seorang individu harus memiliki pola makan sesuai dengan pedoman gizi seimbang (Kementerian Kesehatan RI, 2014).

Pemenuhan gizi seimbang pada balita sangat penting untuk dilakukan, karena kekurangan gizi pada balita akan berdampak pada perkembangan fisik dan juga perkembangan kognitif anak, yang akan berdampak pada produktivitas kerja ketika dewasa.. Selain itu, kekurangan gizi pada balita akan berisiko menyebabkan terjadinya penyakit kronis pada usia dewasa, seperti stroke, diabetes, hipertensi dan penyakit jantnng (Kementerian Kesehatan RI, 2014).

Gizi seimbang pada balita dikategorikan menjadi gizi seimbang untuk bayi 0-6 bulan, gizi seimbang untuk anak 6-24 bulan, dan gizi seimbang untuk anak 2-5 tahun. Gizi seimbang untuk bayi 0-6 bulan adalah cukup dengan ASI atau dikenal dengan istilah ASI Ekslusif. ASI merupakan makanan yang terbaik untuk bayi karena semua zat yang dibutuhkan bayi dari lahir hingga 0-6 bulan terdapat dalam ASI. Selain itu, ASI juga sesuai dengan system pencernaan, murah, dan bersih (Kementerian Kesehatan RI, 2014).

Gizi seimbang pada anak usia 6-24 bulan adalah ASI dan ditambah dengan Makanan Pendamping ASI (MPASI). Pada periode ini, pemberian ASI saja tidak cukup, karena anak mengalami pertumbuhan dan perkembangan yang cepat, dan bayi akan aktif secara fisik. Pada awal pemberian MP-ASI, orang tua bisa memperkenalkan makanan mulai secara bertahap mulai dari bentuk lumat, lembek, hingga makanan keluarga pada usia 1 tahun, begitu juga dengan porsi makannya. Selain itu, sebaiknya ibu memperkenalkan beraneka macam bahan makanan agar bayi mengenal banyak bahan makanan, seperti sayuran, buah, lauk hewani dan lauk nabati (Kementerian Kesehatan RI, 2014).

Semakin bertambahnya usia, maka semakin meningkat juga kebutuhan zat gizi anak. Pemenuhan gizi seimbang apada anak usia 2-5 tahun sebaiknya memperhatikan variasi dan kesukaan anak. Pada tahap ini sebaiknya anak mulai diajarkan untuk dapat memilih makanan sehat dan bergizi, serta diajarkan untuk berperilaku hidup bersih dan sehat, karena anak sudah mulai banyak beraktifitas diluar rumah (Kementerian Kesehatan RI, 2014).

Sebagai upaya untuk meningkatkan pengetahuan masyarakat tentang gizi seimbang pada balita, maka dilakukan kegiatan edukasi kepada masyarakat melalui kegiatan penyuluhan gizi seimbang balita pada ibu balita. Kegiatan penyuluhan gizi seimbang pada ibu balita diikuti oleh 38 ibu balita di Posyandu Catleya 19. Sebelum dilakukan penyuluhan, ibu balita diberikan pretest untuk mengetahui tingkat pengetahuan tentang gizi seimbang pada balita, materi pretest meliputi:

1. Pengertian gizi seimbang

2. Pentingnya gizi seimbang

3. Kecukupan gizi harian anak

4. Aturan pemberian makan pada anak

5. Konsumsi makan anak sehari-hari

Setelah dilakukan pretest, selanjutnta tim melakukan penyuluhan tentang gizi seimbang balita kepada ibu balilta. Untuk mempermudah ibu balita mengikuti kegiatan penyuluha, tim juga memberikan modul gisi seimbang pada balita. Modul yang dibagikan kepada ibu balita dibuat dengan bahasa yang mudah dipahami, serta dilengkapi gambar, dan contoh resep makanan untuk memudahkan pemahaman peserta. Gambaran singkat modul gizi seimbang antara lain:

1. Pengertian seimbang

2. Prinsip gizi seimbang

3. Pentingnya gizi seimbang

4. Angka kecukupan gizi pada balita

5. Aturan pemberian makan pada balita

6. Resep makanan bergizi untuk balita

Dengan mendapatkan materi tersebut diharapkan dapat meningkatkan pengetahuan, kemampuan, dan 
kemauan ibu dalam menyediakan makanan yang memenuhi kebutuhan balita. Setelah dilakukan proses penyampaian materi oleh tim, selanjutnya dilakukan sesi diskusi dan tanya jawab untuk lebih memantapkan pengetahuan ibu tentang gizi seimbang.

Topik yang menjadi perhatian peserta adalah konsumsi sayuran pada balita. Beberapa balita sering menolak apabila diberi sayuran, padalah sayuran memiliki kandungan serat yang baik bagi balita. Hal tersbut terjadi karena sebagian sayuran memiliki rasa yang agak pahit, sehingga anak menganggap bahwa semua sayuran memiliki rasa yang pahit dan tidak untuk memakannya. Sehingga tim mencoba untuk memberikan resep modifikasi sayur seperti nugget, bakso, dan makanan kesukaan anak lainnya. Sehingga rasa pahit dari sayur dapat diminimalisir.

Selain itu, topik GTM (gerakan tutup mulut) juga menjadi topik diskusi. Beberapa ibu balita mengalami kesusahan dalam memberikan makan pada anaknya karena balita tidak mau makan dan hanya mau minum susu. Oleh karena itu, tim memberikan masukan untuk membatasi jumlah susu dan tidak memberikan susu sebelum makan sehingga anak tidak cepat kenyang karena minum susu. Selain itu, pada anak GTM perlu diterapkan aturan makan yang baik, seperti penjadwalan waktu makan, dan memberikan makan porsi kecil dengan intensitas waktu yang sering.

Setelah sesi tanya jawab selesai, selanjutnya dilakukan post test yang akan dijadikan sebagai indicator ecaluasi kesuksesan program penyuluhan pada kegiatan ini. Berdasarkan hasil evaluasi melalui pretest dan post test terdapat 29 ibu balita $(76,3 \%)$ yang memiliki nilai post test lebih tinggi dibandingkan dengan nilai pretest. Hal tersebut menunjukkan bahwa terjadi peningkatan pemahaman tentang gizi seimbang pada ibu balita. Sehingga diharapkan dengan berbekal pengetahuan ibu yang baik tentang gizi akan mempermudah ibu dalam mengasuh anaknya terutama memperhatikan asupan gizi anak sehingga anaknya memiliki status gizi yang baik. Sedangkan ibu yang mempunyai pengetahuan kurang tentang gizi dapat mengakibatkan kurangnya kemampuan untuk menerapkan informasi dalam kehdupan sehari-hari yang merupakan salah satu penyebab terjadinya masalah gizi (Rahardjo, 2017).
Kendala pada kegiatan penyuluhan ini adalah tidak semua ibu datang tepat waktu, sehingga tidak semua ibu mengikuti materi dari awal. Dalam mengatasi permasalahan tersebut, tim pelaksana melakukan penyuluhan secara personal kepada ibu yang datang terlambat. Sehingga semua anggota posyandu mendapatkan materi penyuluhan dengan baik. Kegiatan penyuluhan ini dapat berjalan dengan lancar berkat dukungan dari bidan puskesmas, kader posyandu catelaya 19, dan peran serta dari anggota posyandu.

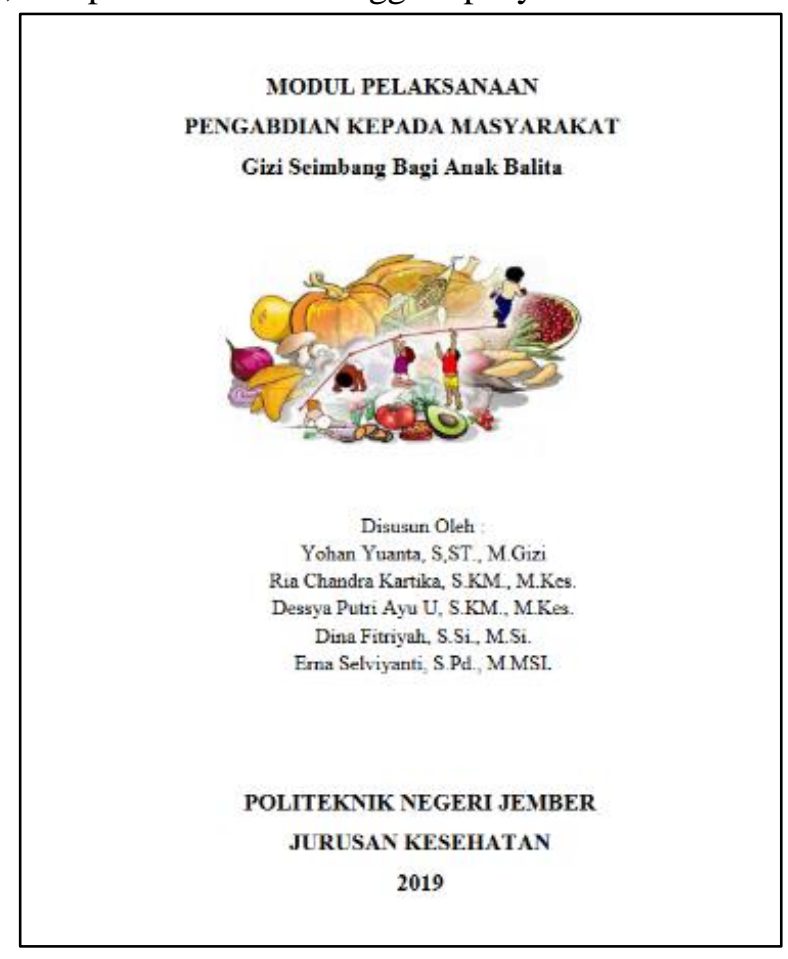

Gambar 2. Modul Penyuluhan Gizi Seimbang

\section{KESIMPULAN}

Gizi seimbang adalah susunan asupan seharihari yang jenis dan jumlah zat gizinya sesuai dengan kebutuhan tubuh. Pemenuhan kebutuhan gizi ini juga harus memperhatikan prinsip keanekaragaman pangan, aktivitas fisik, perilaku hidup bersih dan mempertahankan berat badan normal guna mencegah masalah gizi. Pemantauan gizi pada anak balita perlu dilakukan secara berkesinambungan. Karena permasalahan gizi pada anak terjadi karena banyak faktor yang mempengaruhi baik secara langsung maupun tidak langsung. Pertumbuhan yang tidak optimal pada masa 
balita, akan mempengaruhi status gizinya pada masa remaja dan dewasa nanti. Hasil dari kegiatan penyululuhan gizi seimbang ini menunjukkan bahwa terjadi peningkatan pemahaman tentang gizi seimbang pada ibu balita. Sehingga kegiatan penyuluhan ini efektif untuk meningkatkan pengetahuan ibu tentang gizi seimbang pada balita. Pelaksanaan edukasi gizi kepada masyarakat untuk mencegah permasalahan gizi harus terus dilakukan secara komprehensif. Oleh karena itu perlu dilakukan program pengabdian kepada masyarakat yang selanjutnya seperti mempraktikan cara menyusun menu gizi seimbang, dan mengolah bahan makanan dengan menerapkan gizi seimbang sesuai dengan Angka Kecukupan Gizi (AKG) anak, sehingga contoh tersebut nantinya bisa diaplikasikan sebagai bentuk makanan sehari-hari untuk Anak.

\section{UCAPAN TERIMA KASIH}

Penulis mengucapkan terimakasih kepada pimpinan Politeknik Negeri Jember, Bidan Koordinator Kecamatan Sumbersari, Kader Posyandu Catleya 19, dan ibu balita peserta atas partisipasi aktif dan dukungannya pada pelaksanaan kegiatan pengabdian masyarakat ini.

\section{DAFTAR PUSTAKA}

Almatsier, S. S. S. a. S. M., 2011. Gizi seimbang dalam daur kehidupan. Jakarta: Gramedia Pustaka Utama.

Etikasari, B. P. T. a. K. R., 2020. Pembuatan Aplikasi Berbasis Android Tumbuh Kembang Anak untuk Meningkatkan Taraf Kesehatan dan Manajemen Pelayanan Posyandu Kemuning Lor di Masa Pandemi Covid-19. Jember, Pengabdian Masyarakat: Polije Proceedings Series.

Fadila, R. A. D. a. F. A., 2017. Hubungan Pengetahuan Dan Perilaku Ibu Tentang Gizi Seimbang Dengan Status Gizi Anak Tk Di DesaYosowilangun Lor Kabupaten Lumajang. Jurnal Kesehatan, 5(1), pp. 14-22.

Kementerian Kesehatan RI, 2014. Pedoman Gizi Seimbang. Jakarta: Kementerian Kesehatan RI.

Kementerian Kesehatan RI, 2019. Laporan Nasional Riskesdas 2018, Jakarta: Lembaga Penerbit Badan Penelitian dan Pengembangan Kesehatan.
Kementerian PPN Bappenas, 2019. Pembangunan gizi di indonesia, Jakarta: Direktorat Kesehatan dan Gizi Masyarakat Kedeputian Pembangunan Manusia, Masyarakat dan Kebudayaan Kementerian PPN/Bappenas.

Rahardjo, S. a. W. S., 2017. Peran Ibu yang Berhubungan dengan Peningkatan Status Gizi Balita. Kesmas Indonesia, $3(1)$, pp. 56-65. 